\title{
Synthesis and In Vitro Protein Tyrosine Kinase Inhibitory Activity of Furan-2-yl(phenyl)methanone Derivatives
}

\section{Fei Lang Zheng ${ }^{1}$, Shu Rong Ban ${ }^{1}$, Xiu E Feng ${ }^{1}$, Cheng Xiao Zhao ${ }^{1}$, Wenhan Lin ${ }^{2}$ and Qing Shan Li ${ }^{1,2, *}$}

1 School of Pharmaceutical Science, Shanxi Medical University, Taiyuan 030001, Shanxi, China

2 State Key Laboratory of Natural and Biomimetic Drugs, Peking University, Beijing 100083, China

* Author to whom correspondence should be addressed; E-Mail:qingshanl@yahoo.com;

Tel.: +86-351-4690322; Fax: +86-351-4690114.

Received: 27 April 2011; in revised form: 1 June 2011 / Accepted: 7 June 2011 /

Published: 14 June 2011

\begin{abstract}
A series of novel furan-2-yl(phenyl)methanone derivatives were synthesized, and their structures were established on the basis of ${ }^{1} \mathrm{H}-\mathrm{NMR},{ }^{13} \mathrm{C}-\mathrm{NMR}$ and mass spectral data. All the prepared compounds were screened for their in vitro protein tyrosine kinase inhibitory activity and several new derivatives exhibited promising activity, which, in some cases, was identical to, or even better than that of genistein, a positive reference compound. The preliminary structure-activity relationships of these compounds were investigated and are discussed.
\end{abstract}

Keywords: halophenols; furan-2-yl(phenyl)methanone; protein tyrosine kinases inhibitor; structure-activity relationships (SAR)

\section{Introduction}

Bromophenols isolated from various marine algae, ascidians and sponges have recently attracted much attention due to their unique structures and varied pharmacological activities, which include antioxidative [1], protein tyrosine kinase (PTK) inhibitory [2], anticancer [3], protein tyrosine phosphatase 1B inhibitory [2], antithrombotic [4], antimicrobial [5], anti-inflammatory [6], enzyme inhibitory [7], cytotoxic [8] and appetite suppressant [9] effects. The core structures of these bromophenols are two benzene rings connected by a methylene or carbonyl group. However, studies 
on their structure optimization and their corresponding structure-activity relationship (SAR) with PTK inhibitors have been rarely reported, despite the fact that several natural bromophenol compounds [10] and some new derivatives with antimicrobial activities were prepared [5,11].

Protein kinases play an important role as cell function regulators in signal transduction pathways that regulate a number of cellular functions, such as proliferation, growth, differentiation, death and various regulatory mechanisms. A variety of tumor types have dysfunctional growth factor receptor tyrosine kinases, which result in inappropriate mitogenic signaling. PTKs are, therefore, attractive targets in the search for therapeutic agents, not only against cancer, but also in many other diseases [12,13].

A wide range of heterocyclic ring systems has been studied for the development of novel chemical entities as lead molecules in drug discovery. Introduction of appropriate heterocycles into a lead compound is a common strategy during the drug discovery process. It has been found that many common rings, including different heterocyclic and simplified aromatic structures, are important as PTK inhibitors [14]. The encouraging activities of our previously prepared bromophenols [15] prompted us to investigate new analogs involving further modification of five-membered heterocyclic rings, to optimize the SAR that might lead to potent and selective biological activity. The furan ring is a very important bioactive structure that is considered to be a basic building block in the design and synthesis of new drugs. Furan rings are electron-rich systems that are amenable to act as good ligands for metal ions. Furan derivatives that are substituted at the 2- and 5- positions are frequently found in nature. These derivatives show broad-spectrum pharmacological properties [16]. Hence, in this study, we modified the structures of bromophenols by replacement of one benzene ring with a furan ring. The introduction of new substituents and functional groups at various positions on aromatic or heteroaromatic fragments of a potential drug might lead to changes in its molecular shape that allows optimum binding to the receptor, as well as its physicochemical properties that affect drug distribution and metabolism $[17,18]$. The scaffold was designed in such a way that the benzene ring was connected with heteroaryl system by a carbonyl group, with the hope of attaining superior biological activity. A series of new furan-2-yl(phenyl) methanone derivatives was synthesized by convenient methods to evaluate their biological and PTK inhibitory activities. Finally, the preliminary SARs were investigated.

\section{Results and Discussion}

Two strategies were adopted to prepare the target compounds. One strategy was Friedel-Crafts acylation of substituted benzene derivatives with the furoyl chloride (Schemes 1-3), and the other was Friedel-Crafts acylation of furan with substituted benzoyl chloride derivatives (Schemes 4 and 5).

The synthetic routes of compounds 3a-3d and 4a-4d are shown in Scheme 1. The starting material, furan-2-carboxylic acid, was reacted with dry $\mathrm{SOCl}_{2}$ in the presence of a catalytic amount of $\mathrm{N}, \mathrm{N}$-dimethylformamide (DMF) to yield furan-2-carbonyl chloride, which was reacted further with substituted benzene derivatives to yield compound $\mathbf{3}$. Compound 4 was obtained by treating compound 3 with $\mathrm{BBr}_{3}$.

5-Bromofuran-2-carboxylic acid (5) and 4,5-dibromofuran-2-carboxylic acid (11) were prepared according to the previously described procedures $[19,20]$, which were also used to prepare compounds 7a-7c, 8a-8c, 13 and 14 (Schemes 2 and 3). 
Scheme 1. Syntheis of compounds $3 a-3 d$ and $4 a-4 d$.

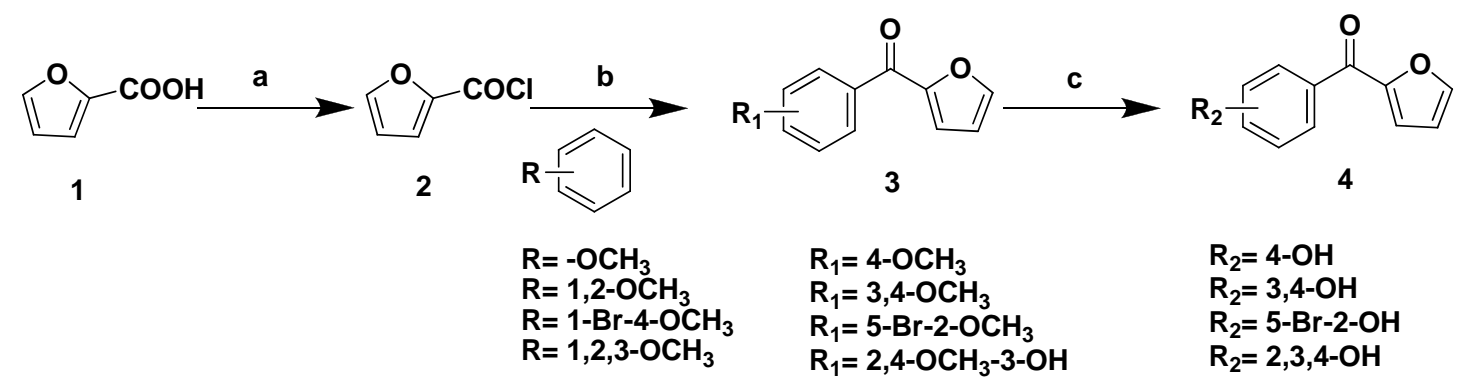

Reagents and conditions: (a) $\mathrm{SOCl}_{2}, \mathrm{DMF}$, reflux, $5 \mathrm{~h}, 95 \%$; (b) $\mathrm{AlCl}_{3}, \mathrm{CH}_{2} \mathrm{Cl}_{2}$, reflux, $8 \mathrm{~h}$, $70 \%-80 \%$; (c) $\mathrm{BBr}_{3}$ (10 equiv.), $\mathrm{CH}_{2} \mathrm{Cl}_{2},-78{ }^{\circ} \mathrm{C}$ to room temperature, $4 \mathrm{~h}, 90 \%-95 \%$.

Scheme 2. Syntheis of compounds $7 \mathrm{a}-7 \mathrm{c}$ and $8 \mathrm{a}-8 \mathrm{c}$.

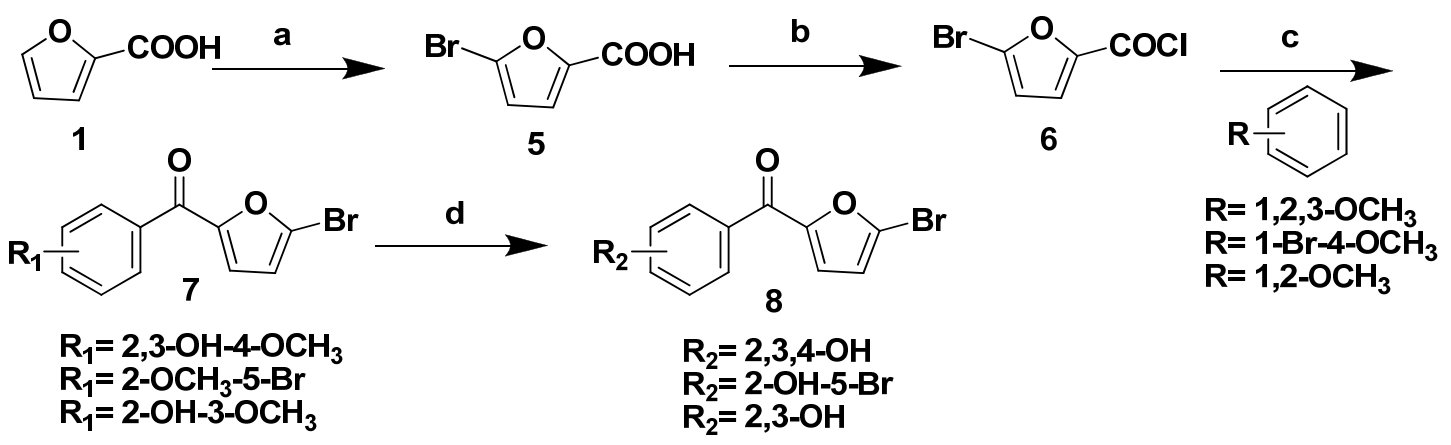

Reagents and conditions: (a) $\mathrm{Br}_{2}, \mathrm{CCl}_{4}$, reflux, $10 \mathrm{~h}, 70 \%$; (b) $\mathrm{SOCl}_{2}$, DMF, reflux, $5 \mathrm{~h}, 90 \%-95 \%$; (c) $\mathrm{AlCl}_{3}, \mathrm{CH}_{2} \mathrm{Cl}_{2}$, reflux, $8 \mathrm{~h}, 70 \%-80 \%$; (d) $\mathrm{BBr}_{3}$ (10 equiv.), $\mathrm{CH}_{2} \mathrm{Cl}_{2},-78{ }^{\circ} \mathrm{C}$ to room temperature, 4 h, $90 \%-95 \%$.

Scheme 3. Syntheis of compounds 13 and 14.

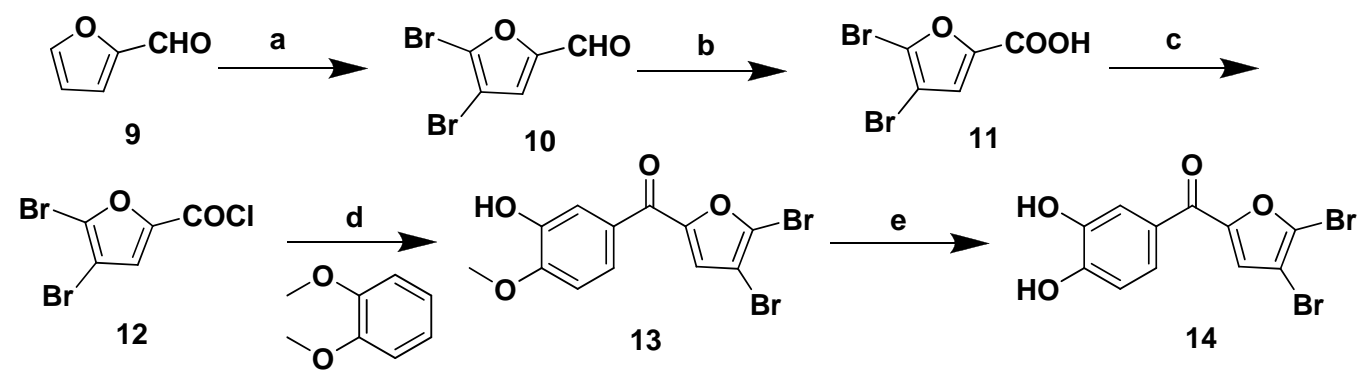

Reagents and conditions: (a) $\mathrm{Br}_{2}, \mathrm{AlCl}_{3}, 0{ }^{\circ} \mathrm{C}, 5 \mathrm{~h}, 60 \%$; (b) $\mathrm{AgNO}_{3}, \mathrm{NaOH}, 3 \mathrm{~h}, 90 \%$; (c) $\mathrm{SOCl}_{2}$, DMF, reflux, 5 h, 95\%; (d) $\mathrm{AlCl}_{3}, \mathrm{CH}_{2} \mathrm{Cl}_{2}$, reflux, $8 \mathrm{~h}, 60 \%$; (e) $\mathrm{BBr}_{3}$ (10 equiv.), $\mathrm{CH}_{2} \mathrm{Cl}_{2},-78{ }^{\circ} \mathrm{C}$ to room temperature, $4 \mathrm{~h}, 91 \%$.

The synthetic routes to compounds $\mathbf{1 7 a} / \mathbf{1 7 b}$ and $\mathbf{1 8 a} / \mathbf{1 8 b}$ are illustrated in Scheme 4. Variously substituted benzoic acids 15 (Figure 1) were refluxed in anhydrous $\mathrm{SOCl}_{2}$ to yield acyl chlorides 16, which were reacted with furfural catalyzed by $\mathrm{AlCl}_{3}$. The product was purified by silica gel column chromatography (ligarine/EtOAc 80:20, v/v) to give compound 17, which were treated with $\mathrm{BBr}_{3}$ to give compound 18. 
Figure 1. Structures of starting materials 15.<smiles>COc1cc(C(=O)O)cc(OC)c1OC</smiles><smiles>COc1ccc(C(=O)O)cc1OC</smiles><smiles>COc1cccc(C(=O)O)c1OC</smiles><smiles>COc1ccc(C(=O)O)cc1</smiles>

Scheme 4. Syntheis of compounds $17 \mathrm{a}-17 \mathrm{~b}$ and $18 \mathrm{a}-18 \mathrm{~b}$.

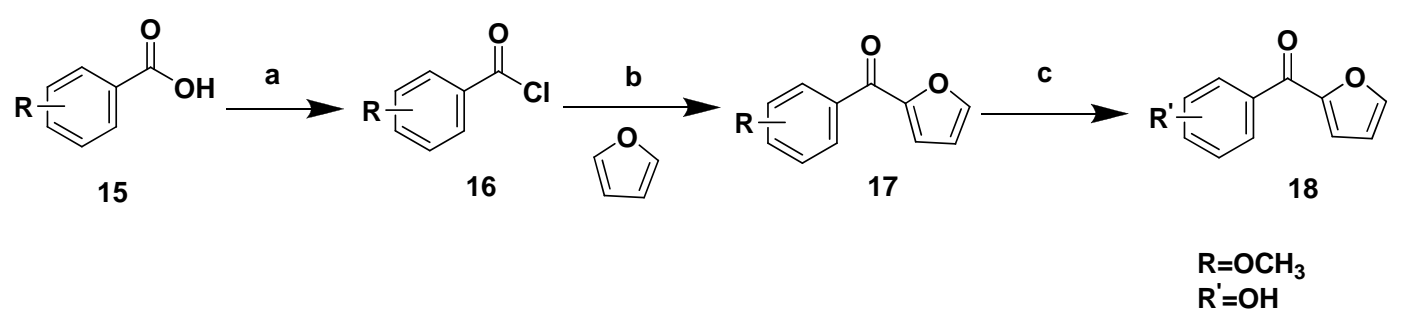

Reagents and conditions: (a) $\mathrm{SOCl}_{2}$, DMF, reflux, $5 \mathrm{~h}, 90 \%-95 \%$; (b) $\mathrm{AlCl}_{3}, \mathrm{CH}_{2} \mathrm{Cl}_{2}, 0{ }^{\circ} \mathrm{C}$ to room temperature, $20 \mathrm{~h}, 80 \%-85 \%$; (c) $\mathrm{BBr}_{3}$ (10 equiv.), $\mathrm{CH}_{2} \mathrm{Cl}_{2},-78{ }^{\circ} \mathrm{C}$ to room temperature, $4 \mathrm{~h}$, $90 \%-95 \%$.

Scheme 5. Syntheis of compounds $21 \mathrm{a}-21 \mathrm{~d}$ and $21 \mathrm{a}-21 \mathrm{~d}$.

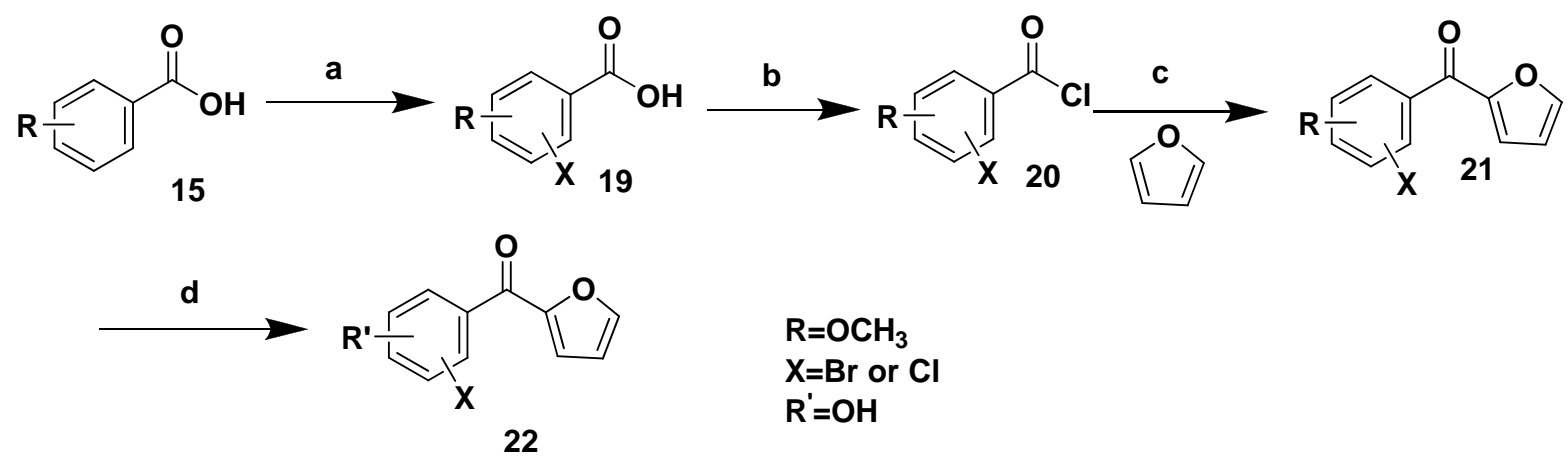

Reagents and conditions: (a) $\mathrm{Br}_{2}, \mathrm{CCl}_{4}, 50{ }^{\circ} \mathrm{C}, 24 \mathrm{~h}, 90 \%-95 \%$ or $\mathrm{SO}_{2} \mathrm{Cl}_{2}, \mathrm{CH}_{2} \mathrm{Cl}_{2}, 40{ }^{\circ} \mathrm{C}, 20 \mathrm{~h}$, 90\%-95\%; (b) $\mathrm{SOCl}_{2}$, DMF, reflux, $5 \mathrm{~h}, 95 \%$; (c) $\mathrm{AlCl}_{3}, \mathrm{CH}_{2} \mathrm{Cl}_{2}, 0{ }^{\circ} \mathrm{C}$ to room temperature, $20 \mathrm{~h}$, $80 \%-85 \%$; (d) $\mathrm{BBr}_{3}$ (10 equiv.), $\mathrm{CH}_{2} \mathrm{Cl}_{2},-78{ }^{\circ} \mathrm{C}$ to room temperature, $4 \mathrm{~h}, 90 \%-95 \%$.

To examine the influence of the number and position of halogen atoms on their bioactivites, chlorination of 15 (Figure 1) with $\mathrm{SO}_{2} \mathrm{Cl}_{2}$ or bromination with $\mathrm{Br}_{2}$ provided a good yield of 19 . Chloro- and bromo-substituted compounds 21 and 22 were then synthesized according to the second route (Scheme 5). The structures of target compounds are shown in Table 1.

Table 1. Structures of the target new compounds.

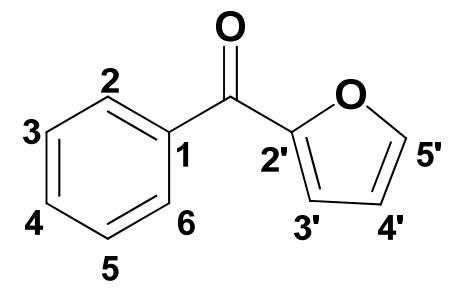


Table 1. Cont.

\begin{tabular}{cccc}
\hline Compounds & Substituent Group & Compounds & Substituent Group \\
\hline 3a & $3,4-\mathrm{OCH}_{3}$ & $\mathbf{4 a}$ & $3,4-\mathrm{OH}$ \\
3b & $2,4-\mathrm{OCH}_{3}, 3-\mathrm{OH}$ & $\mathbf{4 b}$ & $2,3,4-\mathrm{OH}$ \\
3c & $2-\mathrm{OCH}_{3}, 5-\mathrm{Br}$ & $\mathbf{4 c}$ & $2-\mathrm{OH}, 5-\mathrm{Br}$ \\
3d & $4-\mathrm{OCH}_{3}$ & $\mathbf{4 d}$ & $4-\mathrm{OH}$ \\
$\mathbf{7 a}$ & $2,3-\mathrm{OH}, 4-\mathrm{OCH}_{3}, 5^{\prime}-\mathrm{Br}$ & $\mathbf{8 a}$ & $2,3,4-\mathrm{OH}, 5^{\prime}-\mathrm{Br}$ \\
$\mathbf{7 b}$ & $2-\mathrm{OCH}_{3}, 5-\mathrm{Br}^{\prime},-\mathrm{Br}$ & $\mathbf{8 b}$ & $2-\mathrm{OH}, 5-\mathrm{Br}, 5^{\prime}-\mathrm{Br}$ \\
$\mathbf{7 c}$ & $3-\mathrm{OH}, 4-\mathrm{OCH}_{3}, 5^{\prime}-\mathrm{Br}$ & $\mathbf{8 c}$ & $3,4-\mathrm{OH}, 5^{\prime}-\mathrm{Br}$ \\
$\mathbf{1 3}$ & $3-\mathrm{OH}, 4-\mathrm{OCH}_{3}, 4^{\prime}, 5^{\prime}-\mathrm{Br}$ & $\mathbf{1 4}$ & $3,4-\mathrm{OH}, 4^{\prime}, 5^{\prime}-\mathrm{Br}$ \\
$\mathbf{1 7 a}$ & $2,3-\mathrm{OCH}_{3}$ & $\mathbf{1 8 a}$ & $2,3-\mathrm{OH}$ \\
$\mathbf{1 7 b}$ & $2,6-\mathrm{OCH}_{3}$ & $\mathbf{1 8 b}$ & $2,6-\mathrm{OH}$ \\
$\mathbf{2 1 a}$ & $3-\mathrm{Br}_{3}, 4-\mathrm{OCH}_{3}$ & $\mathbf{2 2 a}$ & $3-\mathrm{Br}, 4-\mathrm{OH}$ \\
$\mathbf{2 1 b}$ & $2,6-\mathrm{Br}, 3,4,5-\mathrm{OCH}_{3}$ & $\mathbf{2 2 b}$ & $2,6-\mathrm{Br}, 3,4,5-\mathrm{OH}$ \\
$\mathbf{2 1 c}$ & $2-\mathrm{Cl}, 3,4,5-\mathrm{OCH}_{3}$ & $\mathbf{2 2 c}$ & $2-\mathrm{Cl}, 3,4,5-\mathrm{OH}$ \\
$\mathbf{2 1 d}$ & $2-\mathrm{OH}, 3-\mathrm{OCH}_{3}, 4,5-\mathrm{Br}$ & $\mathbf{2 2 d}$ & $2,3-\mathrm{OH}, 4,5-\mathrm{Br}$ \\
\hline
\end{tabular}

\subsection{Results}

As shown in Table 2, all of the furan-2-yl(phenyl)methanone derivatives were subjected to the in vitro PTK inhibitory activity testing using the PTK assay, as previously reported [13]. Some of the new derivatives exhibited promising activity, which in some cases, was identical to, or even better than that of genistein, a positive reference compound in the same model. Thus, compounds $\mathbf{4 a}, \mathbf{4 b}, \mathbf{8 a}, \mathbf{8 c}$ and 22c exhibited PTK inhibitory activity ( $\mathrm{IC}_{50}$ values 4.66, 6.42, 5.31, 2.72 and $4.62 \mu \mathrm{M}$, respectively), which was more potent than that of the genistein $\left(\mathrm{IC}_{50} 13.65 \mu \mathrm{M}\right)$. Compounds 18a, 18b and 22d also displayed moderate PTK inhibitory activity ( $\mathrm{IC}_{50}$ values $13.23,12.65$ and $9.56 \mu \mathrm{M}$, respectively).

Table 2. PTK inhibitory activity.

\begin{tabular}{cccc}
\hline Compounds & $\begin{array}{c}\text { Protein Tyrosine Kinase } \\
\text { (PTK) inhibition activity }\end{array}$ & Compounds & $\begin{array}{c}\text { Protein Tyrosine Kinase } \\
\text { (PTK) inhibition activity }\end{array}$ \\
\hline 3a & NA & $4 a$ & 4.66 \\
3b & NA & $4 b$ & 6.42 \\
3c & NA & $4 c$ & NA \\
3d & NA & $4 d$ & NA \\
$7 a$ & NA & $8 a$ & 5.31 \\
$7 b$ & NA & $8 b$ & NA \\
$7 c$ & NA & $8 c$ & 2.72 \\
13 & NA & 14 & NA \\
$17 a$ & NA & $18 a$ & 13.23 \\
$17 b$ & NA & $18 b$ & 12.65 \\
$21 a$ & NA & $22 a$ & NA \\
21b & NA & 22b & NA \\
21c & NA & 22c & 4.62 \\
21d & NA & 22d & 9.56 \\
\hline
\end{tabular}

${ }^{\mathrm{a}} \mathrm{IC}_{50}(\mu \mathrm{M})$. Values are means of three experiments; NA, not active at $5 \mu \mathrm{g} / \mathrm{mL}$. Genistein $13.65 \mu \mathrm{M}$. 


\subsection{SAR Analysis}

The results indicated that the number of hydroxyl groups had a great effect on the PTK inhibitory activity. More than one hydroxyl group was essential for the activity, as none of the compounds that had only one hydroxyl group in the phenyl ring showed any activity, whereas those with more than one exhibited high to moderate activity, although the activities did not increase directly with the number of hydroxyl groups. For example, when three hydroxyl groups were present in the phenyl ring, the corresponding activity was lower than that with two hydroxyl groups. Among the hydroxyl substituted derivatives, the three compounds $\mathbf{4 a}, \mathbf{1 8 a}$ and $\mathbf{1 8 b}$ with a similar structure that had two hydroxyl groups in the benzene ring had strong to moderate activity. However, they did not show equal activity, which suggested that two substituent hydroxyl groups at appropriate positions in the benzene ring were important to the PTK inhibitory activity of these compounds.

Comparison of the activities of the halogen-substituted derivatives indicated that the halogen atoms in the phenyl ring (22b and 22c) contributed to the PTK inhibitory activity in the order of $\mathrm{Cl}>\mathrm{Br}$. However, compound 22b with a fully-substituted phenyl ring showed no activity.

We can conclude that hydroxyl groups on the furan-2-yl(phenyl)methanone backbone are essential for the in vitro PTK inhibitory activity of these compounds, and introduction of a methoxyl group can lead to the disappearance of activity, as all the methoxyl derivatives were inactive. The presence of one or more halogen atoms on the phenyl ring also increases the activity. The number and position of the hydroxyl groups and halogen atoms in the phenyl ring could influence the activity potency.

By comparison of the activity of compounds $\mathbf{4 a}, \mathbf{4 b}, \mathbf{8 a}$ and $\mathbf{8 c}$, we found that the introduction of a $\mathrm{Br}$ atom at the $\mathrm{C}-5$ position in the furan ring could increase activity. However, compound $\mathbf{1 4}$ showed no activity due to the introduction of another $\mathrm{Br}$ atom at the $\mathrm{C}-4$ position in the furan ring of $8 \mathrm{c}$ which showed the strongest activity. The results suggest that a $\mathrm{Br}$ atom substituted at the $\mathrm{C}-5$ position in the furan ring could enhance the PTK inhibitory activity, but $\mathrm{Br}$ atoms substituted at the $\mathrm{C}-4$ position in are inhibitory for such activity.

\section{Experimental}

\subsection{General}

Melting points were determined on a XT4A microscopic stage melting point apparatus with an aromatic temperature control system. NMR spectra were recorded on a Bruker-AV400 spectrometer with TMS as an internal standard and DMSO-d6 or $\mathrm{CDCl}_{3}$ as the solvent. Chemical shifts (d values) and coupling constants ( $J$ values) were given in ppm and $\mathrm{Hz}$, respectively. ESI mass spectra were obtained on an API QTRAP 3200 LC-MS spectrometer, the high-resolution mass spectra were obtained on a Bruker Daltonics Apex IV 70e FTICR-MS (Varian 7.0T). TLC analysis was carried out on silica gel plates GF254 (Qingdao Haiyang Chemical, China). Silica gel column chromatography was performed with silica gel $60 \mathrm{G}$ (Qingdao Haiyang Chemical). Commercial solvents were used without any pretreatment, whereas dichloromethane was dried by refluxing and distilling over calcium hydride. 


\subsection{Chemistry}

3.2.1. Procedure for the synthesis of 5-bromofuran-2-carboxylic acid 5

$\mathrm{Br}_{2}(8 \mathrm{~mL})$ was slowly added to a solution of 2-furancarboxylic acid (1, $\left.14.0 \mathrm{~g}\right)$ in $\mathrm{CCl}_{4}(60 \mathrm{~mL})$. The reaction mixture was stirred at $45-50{ }^{\circ} \mathrm{C}$ for $24 \mathrm{~h}$. The solvent was then removed under reduced pressure to yield a red solid which was recrystallized from boiling water to give the compound 5 .

\subsubsection{Procedure for the synthesis of 4,5-dibromofuran-2-carboxylic acid $\mathbf{1 1}$}

Freshly distilled furfural $(10.0 \mathrm{~g})$ was added dropwise with mechanical stirring at $0{ }^{\circ} \mathrm{C}$ to aluminum chloride $(32.0 \mathrm{~g})$ over a two hour period. Bromine $(37.0 \mathrm{~g})$ was then added dropwise at $0{ }^{\circ} \mathrm{C}$ over a two hours period, after which stirring was discontinued and the reaction mixture allowed to stand overnight. The reaction was quenched by carefully pouring the mixture into ice $(800 \mathrm{~mL})$ and then extracting the aqueous layer three times with ether. The combined organics were washed twice with saturated sodium bicarbonate, once with brine, and dried with anhydrous $\mathrm{MgSO}_{4}$. The solvent was removed under reduced pressure to yield a red oil. Purification using column chromatography on silica (hexanes/ethyl acetate $\mathrm{V} / \mathrm{V}=1: 1$ as eluent) yielded compound $\mathbf{1 0}\left(13.2 \mathrm{~g}, \mathrm{R}_{\mathrm{f}}=0.45,20 \%\right.$ ethyl acetate in hexanes) as an orange oil. Next compound $10(13.2 \mathrm{~g}), \mathrm{H}_{2} \mathrm{O}(40.0 \mathrm{~mL})$ and $\mathrm{AgNO}_{3}(8.0 \mathrm{~g})$ were added into a flask and the mixture was stirred at room temperature for $4 \mathrm{~h}$. Then the reaction was completed, $6 \mathrm{M}$ hydrochloric acid adjusted to $\mathrm{PH}$ to $2 \sim 3$, and extracting the aqueous layer three times with ethyl acetate. The combined organics were dried with $\mathrm{Na}_{2} \mathrm{SO}_{4}$. The solvent was removed under reduced pressure, the solid separated was recrystallized from boiling water to give compound $\mathbf{1 1}$.

\subsubsection{General procedure for synthesis of compounds 3a-3d, 7a-7c and $\mathbf{1 3}$}

A solution of 2-furancarboxylic acid $(\mathbf{1}, 1.0 \mathrm{~g})$ and a catalytic amount of DMF in thionyl chloride $\left(5 \mathrm{~mL}\right.$ ) was stirred at $80-90{ }^{\circ} \mathrm{C}$ for $5 \mathrm{~h}$. After concentration under reduced pressure, furoyl chloride 2 was dissolved in dried $\mathrm{CH}_{2} \mathrm{Cl}_{2}$ and reacted with 1,2-dimethoxybenzene ( $1 \mathrm{~mL}$ ) catalyzed by $\mathrm{AlCl}_{3}$. The reaction mixture was heated to $50-60{ }^{\circ} \mathrm{C}$ for $12 \mathrm{~h}$. After the reaction was completed, the reaction was quenched by carefully pouring the mixture into iced water $(100 \mathrm{~mL})$, extracting the aqueous layer three times with $\mathrm{CH}_{2} \mathrm{Cl}_{2}$, and drying with anhydrous $\mathrm{Na}_{2} \mathrm{SO}_{4}$. The solvent was removed under reduced pressure to yield a yellow oil. The residue was purified by silica gel column chromatography (petroleum ether/EtOAc 80:20, v/v) to give compound 3a as a light yellow solid (1.66 g, 80\% yield).

(3,4-Dimethoxyphenyl)(furan-2-yl)methanone (3a). Mol. formula (MW): $\mathrm{C}_{13} \mathrm{H}_{12} \mathrm{O}_{4}$ (232 g/mol); mp: 98-100 ${ }^{\circ} \mathrm{C}$; ${ }^{1} \mathrm{H}-\mathrm{NMR}\left(\mathrm{CDCl}_{3}\right) \delta 7.72(\mathrm{~d}, J=8.4 \mathrm{~Hz}, 1 \mathrm{H}, \mathrm{Ph}-6-\mathrm{H}), 7.67(\mathrm{~s}, 1 \mathrm{H}, \mathrm{Ph}-2-\mathrm{H}), 7.55(\mathrm{~d}$, $\left.J=1.6 \mathrm{~Hz}, 1 \mathrm{H}, 5^{\prime}-\mathrm{H}\right), 7.22$ (d, $\left.J=3.6 \mathrm{~Hz}, 1 \mathrm{H}, 3^{\prime}-\mathrm{H}\right), 6.92$ (d, $\left.J=8.4 \mathrm{~Hz}, 1 \mathrm{H}, \mathrm{Ph}-5-\mathrm{H}\right), 6.57$ (d, $\left.J=2.0 \mathrm{~Hz}, 1 \mathrm{H}, 4^{\prime}-\mathrm{H}\right), 3.94\left(\mathrm{~s}, 6 \mathrm{H}, \mathrm{CH}_{3}\right) ;{ }^{13} \mathrm{C}-\mathrm{NMR}\left(\mathrm{CDCl}_{3}\right) \delta 56.2,56.2,110.1,111.8,112.0,119.6$, $124.1,129.9,146.6,148.6,152.6,153.1,181.0$; ESI-MS $(\%): m / z=233(100)[\mathrm{M}+\mathrm{H}]^{+}, 255(100)$ [M+Na]; HRMS (ESI): Calcd. for [M+H] $]^{+}$233.0808; Found: 233.0811.

Furan-2-yl(3-hydroxy-2,4-dimethoxyphenyl)methanone (3b). Mol. formula (MW): $\mathrm{C}_{13} \mathrm{H}_{12} \mathrm{O}_{5}$ (248 g/mol); light yellow solid; Yield: $75 \%$; mp: $168-170{ }^{\circ} \mathrm{C}$; ${ }^{1} \mathrm{H}-\mathrm{NMR}$ (DMSO-d6) $\delta 8.13$ (d, $J=9.2 \mathrm{~Hz}, 1 \mathrm{H}$, 
Ph-6-H), 7.73 (d, $\left.J=1.6 \mathrm{~Hz}, 1 \mathrm{H}, 5^{\prime}-\mathrm{H}\right), 7.38$ (d, $\left.J=3.6 \mathrm{~Hz}, 1 \mathrm{H}, 3^{\prime}-\mathrm{H}\right), 6.64$ (dd, $J=3.6 \mathrm{~Hz}, J=1.6 \mathrm{~Hz}$, $1 \mathrm{H}, 4$ '-H), 6.58 (d, $J=9.2 \mathrm{~Hz}, 1 \mathrm{H}, \mathrm{Ph}-5-\mathrm{H}), 3.97$, (s, 3H, $\left.\mathrm{OCH}_{3}\right), 3.93\left(\mathrm{~s}, 3 \mathrm{H}, \mathrm{OCH}_{3}\right) ;{ }^{13} \mathrm{C}-\mathrm{NMR}$ (DMSO-d6) $\delta$ 56.1, 60.7, 103.1, 103.2, 112.4, 120.3, 128.2, 136.6, 146.8, 152.2, 158.3, 158.5, 183.9; ESI-MS (\%): $m / z=249(100)[\mathrm{M}+\mathrm{H}]^{+}$; HRMS (ESI): Calcd. for [M+H] $]^{+}$: 249.0758; Found: 249.0759.

(5-Bromo-2-methoxyphenyl)(furan-2-yl)methanone (3c). Mol. formula (MW): $\mathrm{C}_{12} \mathrm{H}_{9} \mathrm{BrO}_{3}$ (281 g/mol); light yellow solid; Yield: 70\%; mp: 66-70 ${ }^{\circ} \mathrm{C}$; ${ }^{1} \mathrm{H}-\mathrm{NMR}\left(\mathrm{CDCl}_{3}\right) \delta 7.68(\mathrm{~s}, 1 \mathrm{H}, 5$ '-H), 7.59 (dd, $\mathrm{J}=8.8 \mathrm{~Hz}$, $J=2.8 \mathrm{~Hz}, 1 \mathrm{H}, \mathrm{Ph}-4-\mathrm{H}), 7.54$ (d, $J=2.8 \mathrm{~Hz}, 1 \mathrm{H}, \mathrm{Ph}-6-\mathrm{H}), 7.09$ (d, $J=4.0 \mathrm{~Hz}, 1 \mathrm{H}, 3$ '-H), 6.91 (d, $J=8.8 \mathrm{~Hz}, 1 \mathrm{H}, \mathrm{Ph}-3-\mathrm{H}), 6.58\left(\mathrm{dd}, J=4.0 \mathrm{~Hz}, J=2.0 \mathrm{~Hz}, 1 \mathrm{H}, 4^{\prime}-\mathrm{H}\right), 3.98\left(\mathrm{~s}, 3 \mathrm{H}, \mathrm{OCH}_{3}\right) ;{ }^{13} \mathrm{C}-\mathrm{NMR}$ $\left(\mathrm{CDCl}_{3}\right) \delta 56.1,112.4,112.5,113.4,120.8,129.6,131.9,134.7,147.6,152.5,156.5,181.2$; ESI-MS (\%): $\mathrm{m} / \mathrm{z}=281(100) 283(98.7)[\mathrm{M}+\mathrm{H}]^{+} 303(100) 305(98.7 \%)[\mathrm{M}+\mathrm{Na}]$.

Furan-2-yl(4-methoxyphenyl)methanone (3d). Mol. formula (MW): $\mathrm{C}_{12} \mathrm{H}_{10} \mathrm{O}_{3}(202 \mathrm{~g} / \mathrm{mol})$; light yellow solid; Yield: $80 \%$; mp: $58-60{ }^{\circ} \mathrm{C}$; ${ }^{1} \mathrm{H}-\mathrm{NMR}\left(\mathrm{CDCl}_{3}\right) \delta 8.06(\mathrm{~s}, 1 \mathrm{H}, \mathrm{Ph}-2-\mathrm{H}), 8.04(\mathrm{~s}, 1 \mathrm{H}, \mathrm{Ph}-6-\mathrm{H}), 7.70$ (s, 1H, 5'-H), 7.25 (d, J=3.6 Hz, 1H, 3'-H), 7.01 (s, 1H, Ph-3-H), 6.99 (s, 1H, Ph-5-H), 6.61 (d, J = 3.6 Hz, $\left.1 \mathrm{H}, 4^{\prime}-\mathrm{H}\right), 3.90\left(\mathrm{~s}, 3 \mathrm{H}, \mathrm{OCH}_{3}\right) ;{ }^{13} \mathrm{C}-\mathrm{NMR}\left(\mathrm{CDCl}_{3}\right) \delta 55.5,112.1,113.7,114.1,119.7,129.8,131.7,132.2$, 146.6, 152.7, 163.3, 181.2; ESI-MS (\%): $m / z=203(100)[\mathrm{M}+\mathrm{H}]^{+} 225(100)[\mathrm{M}+\mathrm{Na}]$.

(5-Bromofuran-2-yl)(2,3-dihydroxy-4-methoxyphenyl)methanone (7a). Mol. formula (MW): $\mathrm{C}_{12} \mathrm{H}_{9} \mathrm{BrO}_{5}$ (313 g/mol); light yellow solid; Yield: 70\%; mp: 128-130 ${ }^{\circ} \mathrm{C} ;{ }^{1} \mathrm{H}-\mathrm{NMR}$ (DMSO-d6) $\delta 11.01$ (br s, $1 \mathrm{H}$, $\mathrm{OH}), 8.83$ (br s, $1 \mathrm{H}, \mathrm{OH}), 7.43$ (dd, $J=8.8 \mathrm{~Hz}, J=2.4 \mathrm{~Hz}, 1 \mathrm{H}, \mathrm{Ph}-6-\mathrm{H}), 7.38$ (d, $J=3.6 \mathrm{~Hz}, 1 \mathrm{H}, 3$ '-H), $6.93(\mathrm{~d}, J=3.6 \mathrm{~Hz}, 1 \mathrm{H}, 4$ '-H), 6.71 (d, $J=8.8 \mathrm{~Hz}, 1 \mathrm{H}, \mathrm{Ph}-5-\mathrm{H}), 3.88$ (s, 3H, $\left.\mathrm{OCH}_{3}\right) ;{ }^{13} \mathrm{C}-\mathrm{NMR}$ (DMSO-d6) $\delta$ 56.4, 104.2, 115.4, 122.4, 122.4, 123.3, 129.2, 134.5, 150.1, 153.3, 153.6, 182.0; ESI-MS (\%): $m / z=313(100) 315(99.1)[\mathrm{M}+\mathrm{H}]^{+} 335$ (100) 337 (99.1\%) [M+Na]; HRMS (ESI): Calcd. for $[\mathrm{M}+\mathrm{H}]^{+}: 312.9706$; Found: 312.9708 .

(5-Bromo-2-methoxyphenyl)(5-bromofuran-2-yl)methanone (7b). Mol. formula (MW): $\mathrm{C}_{12} \mathrm{H}_{8} \mathrm{Br}_{2} \mathrm{O}_{3}$ (360 g/mol); light yellow solid; Yield: $76 \%$; mp: $98-100{ }^{\circ} \mathrm{C} ;{ }^{1} \mathrm{H}-\mathrm{NMR}\left(\mathrm{CDCl}_{3}\right) \delta 7.59$ (dd, $1 \mathrm{H}, \mathrm{J}=8.8 \mathrm{~Hz}$, $J=2.4 \mathrm{~Hz}, \mathrm{Ph}-4-\mathrm{H}$ ), 7.53 (d, $J=2.4 \mathrm{~Hz}, 1 \mathrm{H}, \mathrm{Ph}-6-\mathrm{H}), 7.01$ (d, $J=3.6 \mathrm{~Hz}, 1 \mathrm{H}, 3$ '-H ), 6.91 (d, $J=8.8 \mathrm{~Hz}$, $1 \mathrm{H}, \mathrm{Ph}-3-\mathrm{H}), 6.53$ (d, $\left.J=3.6 \mathrm{~Hz}, 1 \mathrm{H}, 4^{\prime}-\mathrm{H}\right), 3.81\left(\mathrm{~s}, 3 \mathrm{H}, \mathrm{OCH}_{3}\right) ;{ }^{13} \mathrm{C}-\mathrm{NMR}\left(\mathrm{CDCl}_{3}\right) \delta 56.1,112.6$, $113.6,114.5,122.5,128.9,129.9,132.0,135.1,154.1,156.6,179.8 ;$ ESI-MS (\%): $\mathrm{m} / \mathrm{z}=359(51)$ $361(100) 363(50)[\mathrm{M}+\mathrm{H}]^{+} 381$ (51) $383(100) 385(50)[\mathrm{M}+\mathrm{Na}]$.

(5-Bromofuran-2-yl)(3-hydroxy-4-methoxyphenyl)methanone (7c). Mol. formula (MW): $\mathrm{C}_{12} \mathrm{H}_{9} \mathrm{BrO}_{4}$ (297 g/mol); light yellow solid; Yield: 72\%; mp: $128-130{ }^{\circ} \mathrm{C} ;{ }^{1} \mathrm{H}-\mathrm{NMR}\left(\mathrm{CDCl}_{3}\right) \delta 7.67(\mathrm{~s}, 1 \mathrm{H}, \mathrm{Ph}-2-\mathrm{H})$, 7.62 (d, $J=8.4 \mathrm{~Hz}, 1 \mathrm{H}, \mathrm{Ph}-6-\mathrm{H}), 7.32$ (d, $J=3.6 \mathrm{~Hz}, 1 \mathrm{H}, 3$ '-H), 7.12 (d, $J=8.4 \mathrm{~Hz}, 1 \mathrm{H}, \mathrm{Ph}-5-\mathrm{H}), 6.50$ $\left(\mathrm{d}, J=3.6 \mathrm{~Hz}, 1 \mathrm{H}, 4{ }^{\prime}-\mathrm{H}\right) 3.90\left(\mathrm{~s}, 3 \mathrm{H}, \mathrm{OCH}_{3}\right) ;{ }^{13} \mathrm{C}-\mathrm{NMR}\left(\mathrm{CDCl}_{3}\right) \delta 56.2,111.1,113.8,118.0,119.6,122.1$, 123.4, 127.9, 148.6, 152.6, 155.1, 181.0; ESI-MS (\%): m/z = 295 (100) 297 (98.9) [M-H]'; HRMS (ESI): Calcd. for $[\mathrm{M}+\mathrm{H}]^{+}: 296.9757$; Found: 296.9768.

(4,5-Dibromofuran-2-yl)(3-hydroxy-4-methoxyphenyl)methanone (13). Mol. formula (MW): $\mathrm{C}_{12} \mathrm{H}_{8} \mathrm{Br}_{2} \mathrm{O}_{4}$ (376 g/mol); light yellow solid; Yield: 60\%; mp: 107-109 ${ }^{\circ} \mathrm{C} ;{ }^{1} \mathrm{H}-\mathrm{NMR}\left(\mathrm{CDCl}_{3}\right) \delta 7.66(\mathrm{~d}, \mathrm{~J}=8.4 \mathrm{~Hz}$, 1H, Ph-5-H), 7.54 (s, 1H, 3'-H), 7.23 (s, 1H, Ph-2-H), 7.02 (d, J = 8.4 Hz, 1H, Ph-6-H), 3.98 (s, 3H, 
$\left.\mathrm{OCH}_{3}\right) ;{ }^{13} \mathrm{C}-\mathrm{NMR}\left(\mathrm{CDCl}_{3}\right) \delta$ 56.2, 104.3, 111.5, 114.1, 123.2, 124.9, 128.4, 129.0, 146.8, 150.9, 153.6, 180.0; ESI-MS (\%): m/z = 373 (51) 375 (100) 377 (50) [M-H] ${ }^{-}$; HRMS (ESI): Calcd. for [M+H] $]^{+}$ 374.8865; Found: 374.8867.

\subsubsection{General procedure for the synthesis of compounds $\mathbf{1 7 a}$ and $\mathbf{1 7 b}$}

A solution of 2,3-dimethoxybenzoic acid (2.0 g) and a catalytic amount of DMF in thionyl chloride $\left(5 \mathrm{~mL}\right.$ ) was stirred at $80-90{ }^{\circ} \mathrm{C}$ for $3 \mathrm{~h}$. After concentration under reduced pressure, the acid chloride 16 was dissolved in dried $\mathrm{CH}_{2} \mathrm{Cl}_{2}$ and reacted with furan $(3 \mathrm{~mL})$ catalyzed by $\mathrm{AlCl}_{3}$. The reaction mixture was stirred at $0{ }^{\circ} \mathrm{C}$ for $2 \mathrm{~h}$ and then warmed to room temperature and stirred for additional $12 \mathrm{~h}$. After the reaction was completed, the reaction was quenched by carefully pouring the mixture into iced water $(100 \mathrm{~mL})$ and the resultant compound was collected by filtration. Then, the filtrate was extracted with $\mathrm{CH}_{2} \mathrm{Cl}_{2}(3 \times 20 \mathrm{~mL})$, and dried with anhydrous $\mathrm{Na}_{2} \mathrm{SO}_{4}$. The solvent was removed under reduced pressure to yield a brown oil that was purified by silica gel column chromatography (petroleum ether/EtOAc 80:20, v/v) to give (2,3-dimethoxyphenyl)(furan-2-yl)methanone (17a) as light yellow oil (1.78 g, 70\% yield). Molecular formula (MW): $\mathrm{C}_{13} \mathrm{H}_{12} \mathrm{O}_{4}(232 \mathrm{~g} / \mathrm{mol}) ;{ }^{1} \mathrm{H}-\mathrm{NMR}\left(\mathrm{CDCl}_{3}\right) \delta 7.67(\mathrm{~d}, 1 \mathrm{H}$, $\left.J=1.0 \mathrm{~Hz}, 5^{\prime}-\mathrm{H}\right), 7.15$ (dd, $\left.1 \mathrm{H}, J=8.0 \mathrm{~Hz}, J=7.6 \mathrm{~Hz}, \mathrm{Ph}-5-\mathrm{H}\right), 7.08$ (dd, $1 \mathrm{H}, J=8.4 \mathrm{~Hz}, J=1.6 \mathrm{~Hz}$, Ph-4-H), 7.06 (d, $J=3.6$ Hz, 1H, 3'-H), 7.02 (dd, 1H, $J=7.6$ Hz, $J=1.6 \mathrm{~Hz}, \mathrm{Ph}-6-\mathrm{H}), 6.55$ (dd, $J=3.6 \mathrm{~Hz}$, $\left.J=2.0 \mathrm{~Hz}, 1 \mathrm{H}, 4^{\prime}-\mathrm{H}\right), 3.92\left(\mathrm{~s}, 3 \mathrm{H}, \mathrm{OCH}_{3}\right), 3.83\left(\mathrm{~s}, 3 \mathrm{H}, \mathrm{OCH}_{3}\right) ;{ }^{13} \mathrm{C}-\mathrm{NMR}\left(\mathrm{CDCl}_{3}\right) \delta 56.0,62.1,112.3$, $114.7,120.5,121.1,123.9,133.4,147.1,147.5,152.7,152.8,182.8 ;$ ESI-MS (\%): $m / z=233(100)$ $[\mathrm{M}+\mathrm{H}]^{+} 255(100)([\mathrm{M}+\mathrm{Na}]$.

(2,6-Dimethoxyphenyl)(furan-2-yl)methanone (17b). Mol. formula (MW): $\mathrm{C}_{13} \mathrm{H}_{12} \mathrm{O}_{4}(232 \mathrm{~g} / \mathrm{mol})$; light yellow solid; Yield: 85\%; mp: 64-66 ${ }^{\circ} \mathrm{C}$; ${ }^{1} \mathrm{H}-\mathrm{NMR}\left(\mathrm{CDCl}_{3}\right) \delta 7.87(\mathrm{~d}, 1 \mathrm{H}, J=1.0 \mathrm{~Hz}, 5$ '-H) 7.42 $(\mathrm{dd}, 1 \mathrm{H}, J=8.0 \mathrm{~Hz}, J=8.0 \mathrm{~Hz}, \mathrm{Ph}-4-\mathrm{H}), 7.08$ (d, 1H, $J=8.0 \mathrm{~Hz}, J=1.6 \mathrm{~Hz}, \mathrm{Ph}-3-\mathrm{H}), 7.06$ (d, $J=3.6 \mathrm{~Hz}$, 1H, 3'-H), 7.02 (dd, 1H, $J=8.0 \mathrm{~Hz}, J=1.2 \mathrm{~Hz}, \mathrm{Ph}-5-\mathrm{H}), 6.55$ (dd, $J=3.6 \mathrm{~Hz}, J=1.0 \mathrm{~Hz}, 1 \mathrm{H}, 4$ '-H), 3.91 $\left(\mathrm{s}, 3 \mathrm{H}, \mathrm{OCH}_{3}\right), 3.83\left(\mathrm{~s}, 3 \mathrm{H}, \mathrm{OCH}_{3}\right) ;{ }^{13} \mathrm{C}-\mathrm{NMR}\left(\mathrm{CDCl}_{3}\right) \delta 56.0,62.5,112.3,114.7,120.5,121.1,123.9$, $133.3,147.1,147.5,152.7,152.8,182.8$; ESI-MS (\%): $m / z=233(100)[\mathrm{M}+\mathrm{H}]^{+} 255(100)[\mathrm{M}+\mathrm{Na}]$.

\subsubsection{General procedure for the synthesis of compounds 21a-21d}

$\mathrm{Br}_{2}(2 \mathrm{~mL})$ was slowly added to a solution of 4-methoxybenzoic acid $(5.0 \mathrm{~g})$ in $\mathrm{CCl}_{4}(20 \mathrm{~mL})$. The reaction mixture was stirred at $40-45^{\circ} \mathrm{C}$ for $24 \mathrm{~h}$. After concentration under reduced pressure, the residue was re-crystallized from boiling water to give 3-bromo-4-methoxybenzoic acid (19) as white needles. To chlorinate the methoxybenzoic acid, we used $\mathrm{SO}_{2} \mathrm{Cl}_{2}$. A solution of $19(2.0 \mathrm{~g})$ and a catalytic amount of DMF in thionyl chloride $(5 \mathrm{~mL})$ was stirred at $80-90{ }^{\circ} \mathrm{C}$ for $3 \mathrm{~h}$. After concentration under reduced pressure, the acid chloride 20 was dissolved in dried $\mathrm{CH}_{2} \mathrm{Cl}_{2}$ and reacted with furan $(3 \mathrm{~mL})$ catalyzed by $\mathrm{AlCl}_{3}$. The reaction mixture was stirred at $0{ }^{\circ} \mathrm{C}$ for $2 \mathrm{~h}$ and then warmed to room temperature and stirred for an additional $12 \mathrm{~h}$. After the reaction was completed, it was quenched by carefully pouring the mixture into iced water $(100 \mathrm{~mL})$ and the resultant compound was collected by filtration. The filtrate was then extracted with $\mathrm{CH}_{2} \mathrm{Cl}_{2}(3 \times 20 \mathrm{~mL})$ and dried with anhydrous $\mathrm{Na}_{2} \mathrm{SO}_{4}$. The solvent was removed under reduced pressure to yield a brown oil that 
was purified by silica gel column chromatography (petroleum ether/EtOAc 80:20, v/v) to give compound 21a as a light yellow solid (1.85 g, 76\% yield).

(3-Bromo-4-methoxyphenyl)(furan-2-yl)methanone (21a). Mol. formula (MW): $\mathrm{C}_{12} \mathrm{H}_{9} \mathrm{BrO}_{3}(281 \mathrm{~g} / \mathrm{mol}$ ); mp: $112-114{ }^{\circ} \mathrm{C} ;{ }^{1} \mathrm{H}-\mathrm{NMR}\left(\mathrm{CDCl}_{3}\right) \delta 8.30\left(\mathrm{~d}, 1 \mathrm{H}, J=2.0 \mathrm{~Hz}, 5^{\prime}-\mathrm{H}\right), 8.06(\mathrm{dd}, 1 \mathrm{H}, J=8.0 \mathrm{~Hz}, J=2.0 \mathrm{~Hz}$, Ph-6-H), 7.93 (s, 1H, Ph-2-H), 7.30 (d, 1H, J = 3.6 Hz, 3'-H), 7.01 (d, 1H, $J=8.0 \mathrm{~Hz}, \mathrm{Ph}-5-\mathrm{H}), 6.63$ $\left(\mathrm{dd}, J=3.6 \mathrm{~Hz}, J=2.0 \mathrm{~Hz}, 1 \mathrm{H}, 4^{\prime}-\mathrm{H}\right), 4.00\left(\mathrm{~s}, 3 \mathrm{H}, \mathrm{OCH}_{3}\right) ;{ }^{13} \mathrm{C}-\mathrm{NMR}\left(\mathrm{CDCl}_{3}\right) \delta 56.5,111.1,112.3$, $113.7,120.1,130.7,131.7,134.9,146.9,152.3,159.4,179.7$; ESI-MS (\%): $m / z=281(100) 283$ (98.7) $[\mathrm{M}+\mathrm{H}]^{+} 303(100) 305(98.7)[\mathrm{M}+\mathrm{Na}]$.

(2,6-Dibromo-3,4,5-trimethoxyphenyl)(furan-2-yl)methanone (21b). Mol. formula (MW): $\mathrm{C}_{14} \mathrm{H}_{12} \mathrm{Br}_{2} \mathrm{O}_{5}$ (420 g/mol); light yellow solid; Yield: 85\%; mp: 96-98 ${ }^{\circ} \mathrm{C} ;{ }^{1} \mathrm{H}-\mathrm{NMR}\left(\mathrm{CDCl}_{3}\right) \delta 7.71(\mathrm{~d}, \mathrm{~J}=1.0 \mathrm{~Hz}, 1 \mathrm{H}$, $\left.5^{\prime}-\mathrm{H}\right), 7.13\left(\mathrm{~d}, J=3.6 \mathrm{~Hz}, 1 \mathrm{H}, 3^{\prime}-\mathrm{H}\right), 6.61$ (dd, $\left.J=3.6 \mathrm{~Hz}, J=1.6 \mathrm{~Hz}, 1 \mathrm{H}, 4^{\prime}-\mathrm{H}\right), 4.01$ (s, 9H, OCH $)^{\text {); }}$ ${ }^{13} \mathrm{C}-\mathrm{NMR}\left(\mathrm{CDCl}_{3}\right) \delta 61.2,61.4,61.4,110.1,112.9,121.2,136.0,148.3,148.6,151.0,151.1,180.5$; ESI-MS (\%): $m / z=419(51) 421(100) 423(50)[\mathrm{M}+\mathrm{H}]^{+} 441(51) 443$ (100) 445 (50) [M+Na] 457 (51) 459 (100) $461(50)[\mathrm{M}+\mathrm{K}]$.

(2-Chloro-3,4,5-trimethoxyphenyl)(furan-2-yl)methanone (21c). Mol. formula (MW): $\mathrm{C}_{14} \mathrm{H}_{13} \mathrm{ClO}_{5}$ (297 g/mol); light yellow solid; Yield: 82\%; mp: 80-82 ${ }^{\circ} \mathrm{C} ;{ }^{1} \mathrm{H}-\mathrm{NMR}\left(\mathrm{CDCl}_{3}\right) \delta 7.74\left(\mathrm{~s}, 1 \mathrm{H}, 5^{\prime}-\mathrm{H}\right)$, 7.12 (d, $J=3.6 \mathrm{~Hz}, 1 \mathrm{H}, 3$ '-H), 6.80 (s, 1H, Ph-6-H), 6.60 (dd, $\left.J=3.6 \mathrm{~Hz}, J=2.0 \mathrm{~Hz}, 1 \mathrm{H}, 4^{\prime}-\mathrm{H}\right), 3.97$ $\left(\mathrm{s}, 9 \mathrm{H}, \mathrm{OCH}_{3}\right) ;{ }^{13} \mathrm{C}-\mathrm{NMR}\left(\mathrm{CDCl}_{3}\right) \delta 56.3,61.3,61.3,107.0,107.8,112.7,121.4,132.9,145.2,147.9$, 150.3, 152.1, 153.0, 181.5; ESI-MS (\%): $\mathrm{m} / \mathrm{z}=297$ (100) 299 (34) $[\mathrm{M}+\mathrm{H}]^{+} 319$ (100) 321 (34) [M+Na] 335 (100) 337 (34) [M+K]; HRMS (ESI): Calcd. for [M+Na]: 319.0344; Found: 319.0343.

(4,5-Dibromo-2-hydroxy-3-methoxyphenyl)(furan-2-yl)methanone (21d). Mol. formula (MW): $\mathrm{C}_{12} \mathrm{H}_{8} \mathrm{Br}_{2} \mathrm{O}_{4}$ (376 g/mol); light yellow solid; Yield: 80\%; mp: 102-104 ${ }^{\circ} \mathrm{C}$; ${ }^{1} \mathrm{H}-\mathrm{NMR}$ (DMSO-d6) $\delta 9.86$ (br s, 1H, OH), 8.07 (d, 1H, $\left.J=1.2 \mathrm{~Hz}, 5^{\prime}-\mathrm{H}\right), 7.44$ (s, 1H, Ph-6-H), 7.20 (d, $\left.J=3.6 \mathrm{~Hz}, 1 \mathrm{H}, 3^{\prime}-\mathrm{H}\right)$, $6.74\left(\mathrm{dd}, J=3.6 \mathrm{~Hz}, J=2.0 \mathrm{~Hz}, 1 \mathrm{H}, 4^{\prime}-\mathrm{H}\right), 3.89$ (s, 3H, $\left.\mathrm{OCH}_{3}\right) ;{ }^{13} \mathrm{C}-\mathrm{NMR}$ (DMSO-d6) $\delta 57.0,111.4$, 113.6, 113.6, 117.3, 121.6, 129.6, 144.8, 148.6, 149.5, 151.6, 180.6; ESI-MS (\%): $\mathrm{m} / \mathrm{z}=375$ (51) 377 (100) $379(50)[\mathrm{M}+\mathrm{H}]^{+} 397$ (51) 399 (100) 401 (50) [M+Na]; HRMS (ESI): Calcd. for [M+Na]: 396.8682; Found: 396.8683.

\subsubsection{General procedure for the synthesis of compounds $\mathbf{4 a - 4 d , ~ 8 a - 8 c , ~ 1 4 , ~ 1 8 a - 1 8 b ~ a n d ~ 2 2 a - 2 2 d ~}$}

$10 \%$ (equiv.) $\mathrm{BBr}_{3}(2 \mathrm{~mL})$ was added to a solution of compound $3 \mathrm{a}(0.5 \mathrm{~g})$ in $\mathrm{CH}_{2} \mathrm{Cl}_{2}(20 \mathrm{~mL})$. The reaction mixture was stirred at $-78^{\circ} \mathrm{C}$ for $30 \mathrm{~min}$ and then warmed to room temperature and stirred for additional $3.5 \mathrm{~h}$. After the reaction was completed, it was quenched by carefully pouring the mixture into iced water $(100 \mathrm{~mL})$, extraction of the aqueous layer three times with EtOAc, washing with 5\% $\mathrm{NaHSO}_{3}(40 \mathrm{~mL})$ and water $(100 \mathrm{~mL})$, and drying with anhydrous $\mathrm{Na}_{2} \mathrm{SO}_{4}$. The solvent was removed under reduced pressure to yield a light red solid compound $\mathbf{4 a}(0.403 \mathrm{~g}, 91.7 \%$ yield).

Synthesis of (3,4-Dihydroxyphenyl)(furan-2-yl)methanone (4a). Mol. formula (MW): $\mathrm{C}_{11} \mathrm{H}_{8} \mathrm{O}_{4}$ (204 g/mol); mp: $132-134{ }^{\circ} \mathrm{C} ;{ }^{1} \mathrm{H}-\mathrm{NMR}\left(\mathrm{CDCl}_{3}\right) \delta 7.58$ (d, J=8.0 Hz, 1H, Ph-5-H), 7.53 (s, 1H, 5'-H), 7.40 (s, 1H, Ph-2-H), 7.10 (d, J=3.2 Hz, 1H, 3'-H), 6.81 (d, J=8.0 Hz, 1H, Ph-6-H), 6.46 (s, 1H, 4'-H); 
${ }^{13} \mathrm{C}-\mathrm{NMR}\left(\mathrm{CDCl}_{3}\right) \delta 111.8,114.9,116.5,119.7,124.0,129.8,146.6,148.9,152.3,153.0,180.1 ;$ ESI-MS (\%): m/z = 205 (100) [M+H] ${ }^{+}$; HRMS (ESI): Calcd. for [M+Na]: 227.0315; Found: 227.0310.

Furan-2-yl(2,3,4-trihydroxyphenyl)methanone (4b). Mol. formula (MW): $\mathrm{C}_{11} \mathrm{H}_{8} \mathrm{O}_{5}(220 \mathrm{~g} / \mathrm{mol})$; light red solid; Yield: 95\%; mp: 168-170 ${ }^{\circ} \mathrm{C}$; ${ }^{1} \mathrm{H}-\mathrm{NMR}$ (DMSO-d6) $\delta 7.73$ (d, $J=1.6 \mathrm{~Hz}, 1 \mathrm{H}, 5$ '-H), 7.64 (d, $J=9.2 \mathrm{~Hz}, 1 \mathrm{H}, \mathrm{Ph}-6-\mathrm{H}), 7.44$ (d, $\left.J=3.6 \mathrm{~Hz}, 1 \mathrm{H}, 3^{\prime}-\mathrm{H}\right), 6.78$ (dd, $\left.J=3.6 \mathrm{~Hz}, J=1.6 \mathrm{~Hz}, 1 \mathrm{H}, 4^{\prime}-\mathrm{H}\right)$, $6.53(\mathrm{~d}, J=9.2 \mathrm{~Hz}, 1 \mathrm{H}, \mathrm{Ph}-5-\mathrm{H}) ;{ }^{13} \mathrm{C}-\mathrm{NMR}$ (DMSO-d6) $\delta 108.6,113.1,113.2,120.9,123.7,148.5$, 148.7, 151.8, 152.9, 153.3, 183.5; ESI-MS (\%): $\mathrm{m} / \mathrm{z}=219$ (100) [M-H] ${ }^{-}$; HRMS (ESI): Calcd. for [M+Na]: 243.0264; Found: 243.0261.

(5-Bromo-2-hydroxyphenyl)(furan-2-yl)methanone (4c). Mol. formula (MW): $\mathrm{C}_{11} \mathrm{H}_{7} \mathrm{BrO}_{3}(267 \mathrm{~g} / \mathrm{mol}$ ); light red solid; Yield: 94\%; mp: 88-90 ${ }^{\circ} \mathrm{C} ;{ }^{1} \mathrm{H}-\mathrm{NMR}$ (DMSO-d6) $\delta 10.50$ (br s, 1H, OH), 8.08 (d, $\left.J=1.0 \mathrm{~Hz}, 1 \mathrm{H}, 5^{\prime}-\mathrm{H}\right), 7.58$ (d, $\left.J=2.4 \mathrm{~Hz}, 1 \mathrm{H}, \mathrm{Ph}-6-\mathrm{H}\right), 7.56$ (d, $\left.J=8.4 \mathrm{~Hz}, 1 \mathrm{H}, \mathrm{Ph}-4-\mathrm{H}\right), 7.26$ (d, $\left.J=3.6 \mathrm{~Hz}, 1 \mathrm{H}, 3^{\prime}-\mathrm{H}\right), 6.95$ (d, $\left.J=8.4 \mathrm{~Hz}, 1 \mathrm{H}, \mathrm{Ph}-3-\mathrm{H}\right), 6.76$ (dd, $\left.J=3.6 \mathrm{~Hz}, J=2.0 \mathrm{~Hz}, 1 \mathrm{H}, 4^{\prime}-\mathrm{H}\right)$; ${ }^{13} \mathrm{C}-\mathrm{NMR}\left(\mathrm{CDCl}_{3}\right) \delta 110.3,113.4,119.4,121.7,127.5,131.8,135.5,149.1,152.2,156.0,181.7$; ESI-MS (\%): $m / z=265$ (100) 267 (98.6) [M-H] ; HRMS (ESI): Calcd. for [M+Na]: 288.9471; Found: 288.9473 .

Furan-2-yl(4-hydroxyphenyl)methanone (4d). Mol. formula (MW): $\mathrm{C}_{11} \mathrm{H}_{8} \mathrm{O}_{3}$ (188 g/mol); light red solid; Yield: 95\%; mp: $168-170{ }^{\circ} \mathrm{C} ;{ }^{1} \mathrm{H}-\mathrm{NMR}$ (DMSO-d6) $\delta 10.44$ (br s, 1H, OH), 8.07 (d, J = $1 \mathrm{~Hz}$, 1H, 5'-H), 7.89 (s, 1H, Ph-2-H), 7.87 (s, 1H, Ph-6-H), 7.33 (d, J = 3.6 Hz, 1H, 3'-H), 6.93 (s, 1H, Ph-5-H), 6.91 (s, 1H, Ph-3-H), 6.76 (dd, $J=3.6 \mathrm{~Hz}, J=2.4 \mathrm{~Hz}, 1 \mathrm{H}, 4$ '-H); ${ }^{13} \mathrm{C}-\mathrm{NMR}$ (DMSO-d6) $\delta 112.9,115.8,115.8,120.3,128.3,132.1,132.1,148.1,152.2,162.4,180.4$; ESI-MS $(\%): m / z=187$ (100) $[\mathrm{M}-\mathrm{H}]^{-}$; HRMS (ESI): Calcd. for [M+Na]: 211.0366; Found: 211.0368.

(5-Bromofuran-2-yl)(2,3,4-trihydroxyphenyl)methanone (8a). Mol. formula (MW): $\mathrm{C}_{11} \mathrm{H}_{7} \mathrm{BrO}_{5}$ (299 g/mol); light red solid; Yield: 95\%; mp: 132-134 ${ }^{\circ} \mathrm{C}$; ${ }^{1} \mathrm{H}-\mathrm{NMR}$ (DMSO-d6) $\delta 7.48$ (d, $J=8.8 \mathrm{~Hz}$, 1H, Ph-6-H), 7.43 (d, $J=3.6 \mathrm{~Hz}, 1 \mathrm{H}, 3$ '-H), 6.94 (d, $\left.J=3.6 \mathrm{~Hz}, 1 \mathrm{H}, 4^{\prime}-\mathrm{H}\right), 6.50$ (d, $J=8.8 \mathrm{~Hz}, 1 \mathrm{H}$, Ph-5-H); ${ }^{13} \mathrm{C}-\mathrm{NMR}$ (DMSO-d6) $\delta 182.0,158.7,153.3,153.1,147.3,127.2,123.3,120.5,114.8,112.6$, 108.7; ESI-MS (\%): m/z = 297 (100) 299 (99) [M-H] ; HRMS (ESI): Calcd. for [M+Na]: 320.9369; Found: 320.9374 .

(5-Bromo-2-hydroxyphenyl)(5-bromofuran-2-yl)methanone (8b). Mol. formula (MW): $\mathrm{C}_{11} \mathrm{H}_{6} \mathrm{Br}_{2} \mathrm{O}_{3}$ (346 g/mol); light red solid; Yield: 95\%; mp: 82-84 ${ }^{\circ} \mathrm{C}$; ${ }^{1} \mathrm{H}-\mathrm{NMR}$ (DMSO-d6) $\delta 10.46$ (br s, $1 \mathrm{H}, \mathrm{OH}$ ), 7.57 (d, J=8.0 Hz, 1H, Ph-4-H), 7.54 (s, J=8.0 Hz, 1H, Ph-6-H), 7.25 (d, J=3.6 Hz, 1H, 3'-H), 6.95 (d, $J=8.0 \mathrm{~Hz}, 1 \mathrm{H}, \mathrm{Ph}-3-\mathrm{H}), 6.90\left(\mathrm{~d}, J=3.6 \mathrm{~Hz}, 1 \mathrm{H}, 4^{\prime}-\mathrm{H}\right) ;{ }^{13} \mathrm{C}-\mathrm{NMR}$ (DMSO-d6) $\delta 110.3,115.6$, 119.4, 123.8, 127.1, 130.0, 131.9, 135.6, 153.4, 155.7, 180.3; ESI-MS (\%): $\mathrm{m} / \mathrm{z}=343$ (51) 345 (100) 347 (50) $[\mathrm{M}-\mathrm{H}]^{-}$; HRMS (ESI): Calcd. for $[\mathrm{M}+\mathrm{H}]^{+}: 344.8736$; Found: 344.8742.

(5-Bromofuran-2-yl)(3,4-dihydroxyphenyl)methanone (8c). Mol. formula (MW): $\mathrm{C}_{11} \mathrm{H}_{7} \mathrm{BrO}_{4}(283 \mathrm{~g} / \mathrm{mol})$; light red solid; Yield: 95\%; mp: $138-140{ }^{\circ} \mathrm{C} ;{ }^{1} \mathrm{H}-\mathrm{NMR}\left(\mathrm{CDCl}_{3}\right) \delta 7.54(\mathrm{~d}, J=2.0 \mathrm{~Hz}, 1 \mathrm{H}, \mathrm{Ph}-2-\mathrm{H})$, 7.48 (dd, $J=8.4 \mathrm{~Hz}, J=1.6 \mathrm{~Hz}, 1 \mathrm{H}, \mathrm{Ph}-6-\mathrm{H}), 7.12$ (d, $J=3.6 \mathrm{~Hz}, 1 \mathrm{H}, 3$ '-H), 6.94 (d, $J=8.4 \mathrm{~Hz}, 1 \mathrm{H}$, Ph-5-H), 6.49 (d, $\left.J=3.6 \mathrm{~Hz}, 1 \mathrm{H}, 4{ }^{\prime}-\mathrm{H}\right) ;{ }^{13} \mathrm{C}-\mathrm{NMR}\left(\mathrm{CDCl}_{3}\right) \delta 118.8,120.0,121.3,126.2,127.6,132.7$, 
133.0, 150.0, 155.4, 158.9, 184.4; ESI-MS (\%): $\mathrm{m} / \mathrm{z}=283$ (100) 285 (98.8) [M+H] ${ }^{+}$; HRMS (ESI): Calcd. for [M+Na]: 304.9420; Found: 304.9420.

(4,5-Dibromofuran-2-yl)(3,4-dihydroxyphenyl)methanone (14). Mol. formula (MW): $\mathrm{C}_{11} \mathrm{H}_{6} \mathrm{Br}_{2} \mathrm{O}_{4}$ (362 g/mol); light red solid; Yield: 91\%; mp: $184-186{ }^{\circ} \mathrm{C} ;{ }^{1} \mathrm{H}-\mathrm{NMR}\left(\mathrm{CDCl}_{3}\right) \delta 7.53(\mathrm{~s}, 1 \mathrm{H}, \mathrm{Ph}-2-\mathrm{H})$, 7.48 (d, $J=8.0 \mathrm{~Hz}, 1 \mathrm{H}, \mathrm{Ph}-6-\mathrm{H}), 7.18$ (s, $1 \mathrm{H}, 3$ '-H), 6.95 (d, $J=8.0 \mathrm{~Hz}, 1 \mathrm{H}, \mathrm{Ph}-5-\mathrm{H}) ;{ }^{13} \mathrm{C}-\mathrm{NMR}\left(\mathrm{CDCl}_{3}\right)$ $\delta 104.0,115.2,116.5,121.3,122.8,127.7,128.6,145.1,150.9,158.4,179.0 ;$ ESI-MS (\%): $\mathrm{m} / \mathrm{z}=359$ (51) 361 (100) 363 (50) [M-H] ; HRMS (ESI): Calcd. for [M+Na]: 382.8531; Found: 382.8533.

(2,3-Dihydroxyphenyl)(furan-2-yl)methanone (18a). Mol. formula (MW): $\mathrm{C}_{11} \mathrm{H}_{8} \mathrm{O}_{4}(204 \mathrm{~g} / \mathrm{mol})$; light red solid; Yield: 95\%; mp: 64-66 ${ }^{\circ} \mathrm{C} ;{ }^{1} \mathrm{H}-\mathrm{NMR}$ (DMSO-d6) $\delta 8.06$ (d, 1H, J=1.0 Hz, 5'-H), 7.30 (d, $\left.J=3.6 \mathrm{~Hz}, 1 \mathrm{H}, 3^{\prime}-\mathrm{H}\right), 7.10$ (dd, $\left.1 \mathrm{H}, J=8.0 \mathrm{~Hz}, J=1.6 \mathrm{~Hz}, \mathrm{Ph}-6-\mathrm{H}\right), 7.06$ (dd, $1 \mathrm{H}, J=8.4 \mathrm{~Hz}, J=2.0 \mathrm{~Hz}$, Ph-4-H), 6.91 (dd, 1H, $J=8.4 \mathrm{~Hz}, J=8.0 \mathrm{~Hz}, \mathrm{Ph}-5-\mathrm{H}), 6.72\left(\mathrm{dd}, J=3.6 \mathrm{~Hz}, J=2.0 \mathrm{~Hz}, 1 \mathrm{H}, 4^{\prime}-\mathrm{H}\right)$; ${ }^{13}$ C-NMR (DMSO-d6) $\delta$ 109.4, 113.1, 113.6, 120.1, 121.5, 130.0, 144.3, 146.8, 149.4, 151.8, 180.9; ESI-MS (\%): m/z = 203 (100) [M-H] ; HRMS (ESI): Calcd. for [M+Na]: 227.0315; Found: 227.0313.

(2,6-Dihydroxyphenyl)(furan-2-yl)methanone (18b). Mol. formula (MW): $\mathrm{C}_{11} \mathrm{H}_{8} \mathrm{O}_{4}$ (204 g/mol); light red solid; Yield: 95\%; mp: 66-68 ${ }^{\circ} \mathrm{C}$; ${ }^{1} \mathrm{H}-\mathrm{NMR}$ (DMSO-d6) $\delta 8.08$ (d, 1H, J=1.0 Hz, 5'-H), 7.30 (d, $J=3.6 \mathrm{~Hz}, 1 \mathrm{H}, 3^{\prime}-\mathrm{H}$ ), 7.17 (dd, 1H, $\left.J=8.0 \mathrm{~Hz}, J=1.6 \mathrm{~Hz}, \mathrm{Ph}-3-\mathrm{H}\right), 7.04$ (dd, $1 \mathrm{H}, J=8.4 \mathrm{~Hz}, J=2.0 \mathrm{~Hz}$, Ph-5-H), 6.81 (dd, 1H, $J=8.4 \mathrm{~Hz}, J=8.0 \mathrm{~Hz}, \mathrm{Ph}-4-\mathrm{H}), 6.76$ (dd, $J=3.6 \mathrm{~Hz}, J=2.0 \mathrm{~Hz}, 1 \mathrm{H}, 4$ '-H); ${ }^{13} \mathrm{C}-\mathrm{NMR}$ (DMSO-d6) $\delta$ 113.2, 119.4, 119.6, 120.5, 121.6, 123.9, 146.5, 147.4, 148.9, 152.2, 184.0; ESI-MS (\%): m/z = 203 (100) [M-H] ; HRMS (ESI): Calcd. for [M+Na]: 227.0315; Found: 227.0310.

(3-Bromo-4-hydroxyphenyl)(furan-2-yl)methanone (22a). Mol. formula (MW): $\mathrm{C}_{11} \mathrm{H}_{7} \mathrm{BrO}_{3}(267 \mathrm{~g} / \mathrm{mol}$ ); light red solid; Yield: 90\%; mp: 100-102 ${ }^{\circ} \mathrm{C}$; ${ }^{1} \mathrm{H}-\mathrm{NMR}$ (DMSO-d6) $\delta 11.32$ (br s, 1H, OH), 8.10 (d, $1 \mathrm{H}, J=2.8 \mathrm{~Hz}, \mathrm{Ph}-2-\mathrm{H}), 8.09$ (d, 1H, $\left.J=2.0 \mathrm{~Hz}, 5^{\prime}-\mathrm{H}\right), 7.90$ (dd, 1H, $J=8.8 \mathrm{~Hz}, J=2.4 \mathrm{~Hz}, \mathrm{Ph}-6-\mathrm{H}$ ), 7.40 (d, $\left.J=3.6 \mathrm{~Hz}, 1 \mathrm{H}, 3^{\prime}-\mathrm{H}\right), 7.12$ (d, $\left.1 \mathrm{H}, J=8.8 \mathrm{~Hz}, \mathrm{Ph}-5-\mathrm{H}\right), 6.79$ (dd, $J=3.6 \mathrm{~Hz}, J=2.0 \mathrm{~Hz}, 1 \mathrm{H}$, 4 '-H); ${ }^{13}$ C-NMR (DMSO-d6) $\delta$ 110.0, 113.1, 116.5, 120.9, 129.6, 131.1, 134.7, 148.6, 151.9, 158.9, 179.2; ESI-MS (\%): m/z = 265 (100) 267 (98.6) [M-H] ; HRMS(ESI): Calcd. for [M+Na]: 288.9472; Found: 288.9470.

(2,6-Dibromo-3,4,5-trihydroxyphenyl)(furan-2-yl)methanone (22b). Mol. formula (MW): $\mathrm{C}_{11} \mathrm{H}_{6} \mathrm{Br}_{2} \mathrm{O}_{5}$ (378 g/mol); light red solid; Yield: 93\%; mp: 148-150 ${ }^{\circ} \mathrm{C}$; ${ }^{1} \mathrm{H}-\mathrm{NMR}$ (DMSO-d6) $\delta 9.82$ (br s, 2H, OH), 9.58 (br s, 1H, OH), 8.07 (d, $\left.J=1.6 \mathrm{~Hz}, 1 \mathrm{H}, 5^{\prime}-\mathrm{H}\right), 7.13$ (d, $\left.J=3.6 \mathrm{~Hz}, 1 \mathrm{H}, 3^{\prime}-\mathrm{H}\right), 6.74$ (dd, $J=3.6 \mathrm{~Hz}$, $J=1.6 \mathrm{~Hz}, 1 \mathrm{H}, 4{ }^{\prime}-\mathrm{H}$ ); ${ }^{13} \mathrm{C}-\mathrm{NMR}$ (DMSO-d6) $\delta$ 99.1, 113.6, 113.7, 121.9, 130.9, 136.9, 143.8, 143.8 , 149.7, 151.3, 181.4; ESI-MS (\%): m/z = 375 (51) 377 (100) 379 (50) [M-H] ; HRMS (ESI): Calcd. for $[\mathrm{M}+\mathrm{H}]^{+}: 378.8635$; Found: 378.8637 .

(2-Chloro-3,4,5-trihydroxyphenyl)(furan-2-yl)methanone (22c). Mol. formula (MW): $\mathrm{C}_{11} \mathrm{H}_{7} \mathrm{ClO}_{5}$ (255 g/mol); light red solid; Yield: 94\%; mp: 150-152 ${ }^{\circ} \mathrm{C}$; ${ }^{1} \mathrm{H}-\mathrm{NMR}$ (DMSO-d6) $\delta 9.65$ (br s, 3H, OH), 9.42 (br s, 3H, OH), 8.07 (s, 1H, 5'-H), 7.14 (d, J=3.6 Hz, 1H, 3'-H), 6.74 (dd, $J=3.6 \mathrm{~Hz}, J=1.6 \mathrm{~Hz}$, $\left.1 \mathrm{H}, 4{ }^{\prime}-\mathrm{H}\right), 6.25$ (s, 1H, Ph-6-H); ${ }^{13} \mathrm{C}-\mathrm{NMR}$ (DMSO-d6) $\delta 108.1,113.3,121.8,127.8,137.4,143.5$, 144.5, 146.1, 149.1, 152.2, 181.4; ESI-MS (\%): $m / z=253$ (100) 255 (33.7) [M-H] ; HRMS (ESI): 
Calcd. for [M+Na]: 276.9874; Found: 276.9876.

(4,5-Dibromo-2,3-dihydroxyphenyl)(furan-2-yl)methanone (22d). Mol. formula (MW): $\mathrm{C}_{11} \mathrm{H}_{6} \mathrm{Br}_{2} \mathrm{O}_{4}$ (362 g/mol); light red solid; Yield: 95\%; mp: 138-140 ${ }^{\circ} \mathrm{C}$; ${ }^{1} \mathrm{H}-\mathrm{NMR}$ (DMSO-d6) $\delta 9.66$ (br s, $1 \mathrm{H}, \mathrm{OH}$ ), 9.37 (br s, 1H, OH), 8.07 (s, 1H, 5'-H), 7.40 (s, 1H, Ph-6-H), 7.14 (d, J = 3.6 Hz, 1H, 3'-H), 6.74 (dd, $J=3.6 \mathrm{~Hz}, J=2.0 \mathrm{~Hz}, 1 \mathrm{H}, 4^{\prime}-\mathrm{H}$ ); ${ }^{13} \mathrm{C}-\mathrm{NMR}$ (DMSO-d6) $\delta 108.1,109.3,113.3,120.0,121.8,127.8$, 143.5, 144.5, 149.1, 152.2, 181.4; ESI-MS (\%): $m / z=359$ (51) 361 (100) 363 (50) [M-H] ; HRMS (ESI): Calcd. for $[\mathrm{M}+\mathrm{Na}]: 382.8526$; Found: 382.8528 .

\section{Biological Evaluation}

\subsection{PTK Inhibitory Activity}

The activities of PTKs were tested using ELISA. The tyrosine kinase was extracted from brain tissue of rat, and microtiter plates were coated using poly-Glu-Tyr (PGT) as substrates. If the tyrosine residues of PGT were phosphorylated by PTKs, they bound to phospho-specific monoclonal antibody that was labeled specifically with HRP. The absorbance was measured to reflect the activity of PTK.

\subsection{Tyrosine Kinase Assay}

The phosphorylation assays were performed at $37{ }^{\circ} \mathrm{C}$ in a final volume of $40 \mu \mathrm{L}$ tyrosine kinase. The concentrations of PTKs used to construct calibration curves were as follows: 600, 500, 400, 300, 200 and $100 \times 10^{-7} \mathrm{U} / \mathrm{mL}$ for PTK. A concentration of $500 \times 10^{-7} / \mu \mathrm{L}$ was used for each inhibitor. Phosphorylation reactions were initiated with the addition of $40 \mathrm{mM}$ ATP $(10 \mu \mathrm{L})$ into each vessel, and the plate was incubated at $37^{\circ} \mathrm{C}$ for $30 \mathrm{~min}$. After completion of reaction, liquid was decanted and the vessels were washed four times with Tween-PBS. One hundred microliters of blocking solution was added to the vessels and incubated at $37^{\circ} \mathrm{C}$ for $30 \mathrm{~min}$. After washing the plate with Tween-PBS, anti-phosphotyrosine $(50 \mu \mathrm{L})$ was added to the vessels and incubated at $37{ }^{\circ} \mathrm{C}$ for $30 \mathrm{~min}$. The reaction liquid was decanted and the remaining solution was removed by rinsing four times with Tween-PBS. One hundred $\mu \mathrm{L}$ of HRP coloring agent was added and incubated at $37{ }^{\circ} \mathrm{C}$ for $15 \mathrm{~min}$. The reaction was terminated by addition of $1 \mathrm{~N}$ sulfuric acid $(100 \mu \mathrm{L} /$ well). The absorbance of the reaction was measured at $450 \mathrm{~nm}$ on a microplate reader.

\section{Conclusions}

In summary, a number of new furan-2-yl(phenyl) methanone derivatives were synthesized and evaluated for their in vitro PTK inhibitory activity. Several new derivatives exhibited promising activity, which in some cases was identical to, or even stronger than, that of genistein, a positive reference compound.

The results justify further studies on these types of derivatives with significant pharmacological (PTK inhibitory) value. 


\section{Acknowledgements}

This work was financially supported by the State "Innovative Drugs Development" Key and Technology Major Projects of China (No. 2009ZX09302-003), by the State Key Laboratory of Natural and Biomimetic Drugs, Peking University (No. 20080210), by the Shanxi Foundation for Returning Overseas Scientists, by the Program for the Top Science and Technology Innovation Teams of Higher Learning Institutions of Shanxi, by the Program for the Top Young and Middle-aged Innovative Talents of Higher Learning Institutions of Shanxi Province and by Shanxi Province Foundation Science for Youths (No. 2009021041-1).

\section{References and Note}

1. Li, K.; Li, X.M.; Ji, N.Y.; Wang, B.G. Natural bromophenols from the marine red alga Polysiphonia urceolata (Rhodomelaceae): Structural elucidation and DPPH radical-scavenging activity. Bioorg. Med. Chem. 2007, 15, 6627-6631.

2. Liu, Q.W.; Xu, H.; Zhang, T.; Fan, X.; Han, L.J. A new compound as PTP1B inhibitor from the red alga Polysiphonia urceolata. Chemistry 2006, 9, 708-710.

3. Han, L.J.; Xun, J.; Shi, J.G.; Yan, X.J.; Zeng, C.K. Isolation and pharmacological activities of bromophenols from Rhodomela confervoides. Chin. J. Oceanol. Limnol. 2005, 23, 226-229.

4. Shi, D.Y.; Li, J.; Guo, S.J.; Han, L.J. Antithrombotic effect of bromophenol, the alga-derived thrombin inhibitor. J. Biotechnol. 2008, 136S, S577-S588.

5. Oh, K.B.; Lee, J.H.; Lee, J.W.; Yoon, K.M.; Chung, S.C.; Jeon, H.B.; Shin, J.H.; Lee, H.S. Antimicrobial activities of the bromophenols from the red alga Odonthalia corymbifera and some synthetic derivatives. Bioorg. Med. Chem. Lett. 2008, 18, 104-108.

6. Popplewell, W.L.; Northcote, P.T. Colensolide A: A new nitrogenous bromophenol from the New Zealand marine red alga Osmundaria colensoi. Tetrahedron Lett. 2009, 50, 6814-6817.

7. Wang, W.; Okada, Y.; Shi, H.B.; Wang, Y.Q.; Okuyama, T. Structures and aldose reductase inhibitory effects of bromophenols from the red alga Symphyocladia latiuscula. J. Nat. Prod. 2005, 68, 620-622.

8. Xu, X.L.; Song, F.H.; Wang, S.J.; Li, S.; Xiao, F.; Zhao, J.L.; Yang, Y.C.; Shang, S.Q.; Yang, L.; Shi, J.G. Dibenzyl bromophenols with diverse dimerization patterns from the brown alga Leathesia nana. J. Nat. Prod. 2004, 67, 1661-1666.

9. Kurata, K.; Taniguchii, K.; Takashima, K.; Hayash, I.; Suzuki, M. Feeding-deterrent bromophenols from Odonthalia corymbifera. Phytochemistry 1997, 45, 485-487.

10. Abdel-Lateff, A. Chaetominedione, a new tyrosin kinase inhibitor isolated from the algicolous marine fungus Chaetomium sp. Tetrahedron Lett. 2008, 49, 6398-6400.

11. Oh, K.B.; Lee, J.H.; Lee, J.W.; Yoon, K.M.; Chung, S.C.; Jeon, H.B.; Shin, J.H.; Lee, H.S. Synthesis and antimicrobial activities of halogenated bis(hydroxyphenyl)methanes. Bioorg. Med. Chem. Lett. 2009, 19, 945-948.

12. Traxler, P.; Furet, P. Strategies toward the design of novel and selective protein tyrosine kinase inhibitors. Pharmacol. Ther. 1999, 82, 195-206. 
13. Hori, H.; Nagasawa, H.; Uto, Y.; Ohkura, K.; Kirk, K.L.; Uehara, Y.; Shimamura, M. Design of hypoxia-targeting protein tyrosine kinase inhibitor using an innovative pharmacophore 2-methylene-4-cyclopentene-1,3-dione. Biochim. Biophys. Acta 2004, 1697, 29-38.

14. Altuntas, T.G.; Olgen, S.; Nebioglu, D.; Akaho, E. A study on the interaction between p60 $0^{\text {c-Src }}$ receptor tyrosine kinase and arylcarboxylic and arylacetic acid derivatives based on docking modes and in vitro activity. Biol. Pharm. Bull. 2004, 27, 61-65.

15. Zhao, W.Y.; Feng, X.E.; Ban, S.R.; Lin, W.H.; Li, Q.S. Synthesis and biological activity of halophenols as potent antioxidant and cytoprotective agents. Bioorg. Med. Chem. Lett. 2010, 14, 4132-4134.

16. Cui, Z.N.; Li, Y., Ling, Y.; Huang, J.; Cui, J.R.; Wang, R.Q.; Yang, X.L. New class of potent antitumor acylhydrazone derivatives containing furan. Eur. J. Med. Chem. 2010, 45, 5576-5584.

17. Patrick, G.L. An Introduction to Medicinal Chemistry, 3rd ed.; Oxford University Press: New York, NY, USA, 2005; pp. 271-298.

18. Kumar, D.; Kumar, N.M.; Chang, K.H. Synthesis and anticancer activity of 5-(3-indolyl)-1,3,4-thiadiazoles. Eur. J. Med. Chem. 2010, 45, 4664-4668.

19. Joule, J.A.; Mills, K. Heterocyclic Chemistry, 4th ed.; Blackwell Science Ltd: Oxford, UK, 2000; pp. 335-356.

20. Young, I.S.; Kerr, M.A. Total synthesis of (+)-nakadomarin. J. Am. Chem. Soc. 2007, 129, 1465-1469.

Sample Availability: Samples are available from the authors.

(C) 2011 by the authors; licensee MDPI, Basel, Switzerland. This article is an open access article distributed under the terms and conditions of the Creative Commons Attribution license (http://creativecommons.org/licenses/by/3.0/). 